the AL group were quite active but did not leave the 11-in. circle because they tended to keep their rear segments anchored to the substrate. Ss of the AD group displayed little activity, indicating perhaps that this condition included the essential components of an earthworm's home burrow.
REFERENCES

RATNER, S. C.. \& GARDNER, L. E. Variables affecting responses of earthworms to light. Joumal of Comparative \& Physiological Psychology, 1968,66, 239-243.

SMITH, A. C. The influence of temperature, odors, light and contact on movements of the earthworm. American Journal of Physiology, 1902, 6, 459-486.

\title{
The developmental aspect of marking and nesting behaviors in Mongolian gerbils (Meriones unguiculatus)*
}

\author{
C. T. LEE and DANIEL ESTEP \\ The University of Texas, Austin, Tex, 78712
}

The marking and nest-building behaviors of male and female gerbils were studied developmentally. Gerbils of both sexes began to mark at 5 weeks of age, though males did not mark more of ten than females until 16 weeks of age. Both males and females were able to use cotton to build nests at 5 weeks of age. No sex difference was found in cotton consumption at any age level. The marking and nesting activities were positive functions of age.

The purpose of the present study is to investigate the development of marking and nesting behaviors in male and female gerbils.

\section{EXPERIMENT 1:}

MARKING BEHAVIOR

Mongolian gerbils have been observed to mark prominent objects in their environment with the midventral sebaceous gland pads. This behavior has been studied extensively by Thiessen and his associates (Thiessen, 1968a, b; Thiessen, Friend, \& Lindzey, 1968 ). Marking behavior is sex-dimorphic, androgen-dependent, and appears to relate to territoriality (Thiessen, 1968a). Lindzey, Thiessen, \& Tucker (1968) reported that male gerbils began to mark at 70 days of age and showed a high degree of marking activity at about 100 days of age. Gerbils of both sexes were studied in the present experiment.

\section{Subjects}

Upon arrival, 10 males and 10

* This work was supported by National Science Foundation-University Science Development Program Grant GU-1598. females, purchased from Tumblebrook Farm at 28 days of age, were housed singly in cages measuring $11^{1 / 2} \times 7 \frac{1 / 4}{4} 5$ in. and maintained ad lib with water and Purina Lab Chow.

Apparatus

The Ss were housed in an air-conditioned room with a mean temperature of $76^{\circ} \mathrm{F}\left(74^{\circ}\right.$ to $\left.78^{\circ}\right)$. The laboratory had a 12-h light-dark cycle. Polypropylene cages and chrome-plated lids from Lab Cages, Inc., were used to house Ss. The testing apparatus was a black plastic box of $24 \times 24 \times 18$ in. with a front transparent observation window. Six pegs ( $1 \times 1 / 2 \times 1 / 8$ in.) were arranged in two rows of three each, with equal spacing among pegs. The box was illuminated with a $15-\mathrm{W}$ fluorescent light during testing.

\section{Procedure}

Ss at 4 weeks of age were tested in a random sequence once a week for 13 weeks. The $S$ was placed in the center of the apparatus and observed for $5 \mathrm{~min}$. The number of marks were recorded. The apparatus was cleaned with $50 \%$ Ethonal before and after testing of each $S$. At the end of the experiment, the sebaceous gland sizes of the Ss were measured.

Results and Discussion

Figure 1 presents the number of marks exhibited by the gerbils. The analysis of variance showed that there was a significant main day effect $(\mathrm{F}=6.06, \mathrm{df}=12 / 216, \mathrm{p}<.01)$, and both males and females indicated significant day effects $(F=4.06,1.84$, and $\mathrm{p}<.01, .05$ for males and females, respectively; $\mathrm{df}=12 / 117$ in both cases). The positive correlation between marking scores and age is in agreement with findings of Lindzey et al (1968), and the number of marks exhibited by male gerbils at approximately 100 days of age observed in the present study are also similar to those reported by Lindzey et al. However, there are differences between these two studies in the time of onset of marking behavior. While Lindzey et al found that male gerbils did not mark until approximately 70 days of age, the present study showed that gerbils of both sexes began to mark as early as 35 days of age. The discrepancy may be due to differences in sampling or housing conditions.

Sex differences in the marking scores almost approached the significant level $(F=4.27, \mathrm{df}=1 / 18$, $\mathrm{p}<.10$ ). Daily sex comparisons revealed that males marked more frequently than females at 16 weeks of age but not at any other age level. The significant Sex by Day interaction further indicated that the increase of marking scores proceeded differentially in males and females along the age dimension $(F=2.72$, $\mathrm{df}=12 / 216, \quad \mathrm{p}<.01)$. Thiessen (1968a) also stated that adult males marked more frequently than adult females.

The Mann-Whitney test indicated that the mean gland size of males ( $\mathrm{L} \times \mathrm{W}, 1.75 \times 0.47 \mathrm{~mm}$ ) was significantly larger than that of females $(0.26 \times 0.06 \mathrm{~mm}) \quad(p<.01)$. The results are congruent with reports by Thiessen (1968a) and Lindzey et al (1968).

\section{EXPERIMENT 2:}

\section{NEST-BUILDING BEHAVIOR}

Gerbils have been reported to use leaves of buckwheat, Graminaceae and Cyperaceae to build round nests about 18-25 cm in diam (Schwentker, 1965), and to shred papers of various thickness to build nests (Glickman, Fried, \& Morrison, 1967). Cotton was used as nesting material to investigate nesting activity in this study.

The Ss were those used in Experiment 1; they were tested and maintained under the same conditions. 


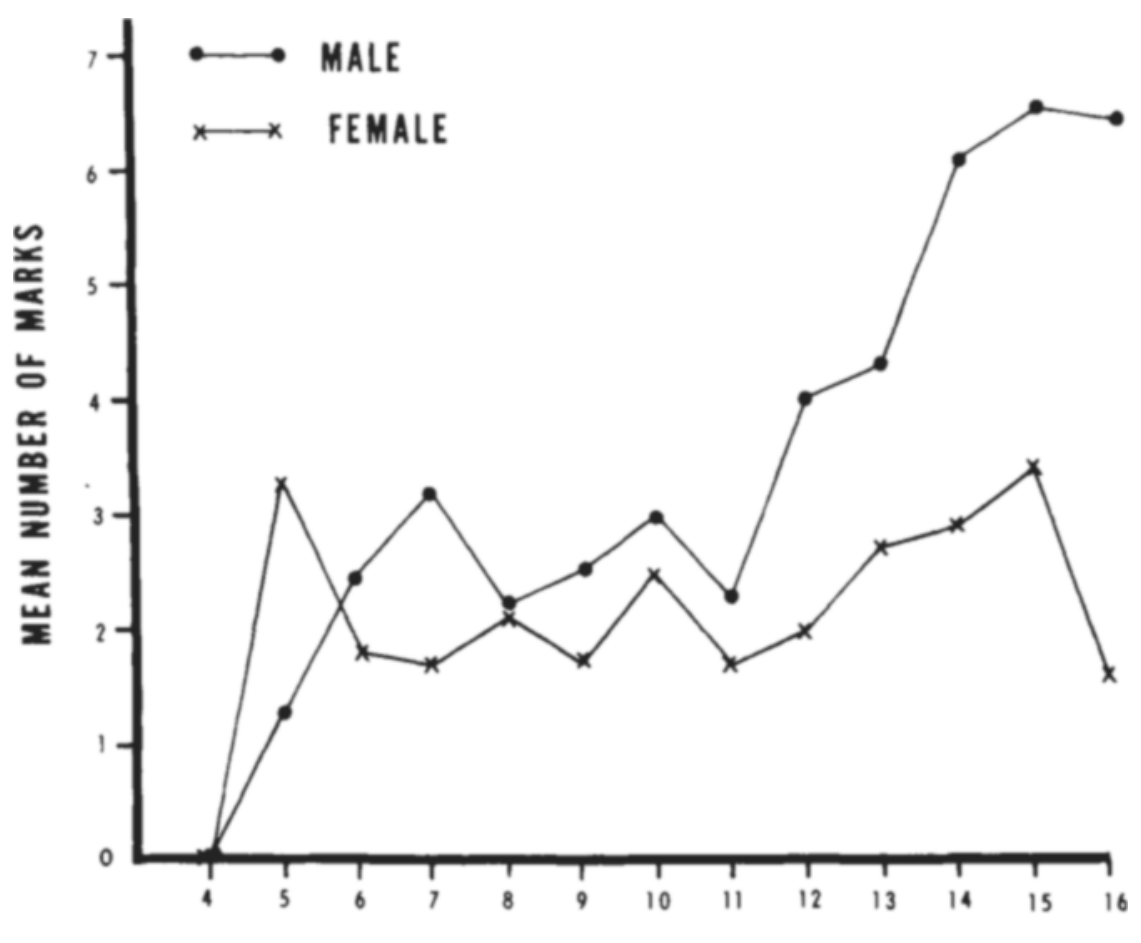

AGE IN WEEKS

Fig. 1. Mean number of marks exhibited by gerbils at various ages in a 5-min testing period.

Apparatus

Cotton was used as nesting material. A Sartorius Digital Precision Balance was used to measure both $S$ and cotton weight.

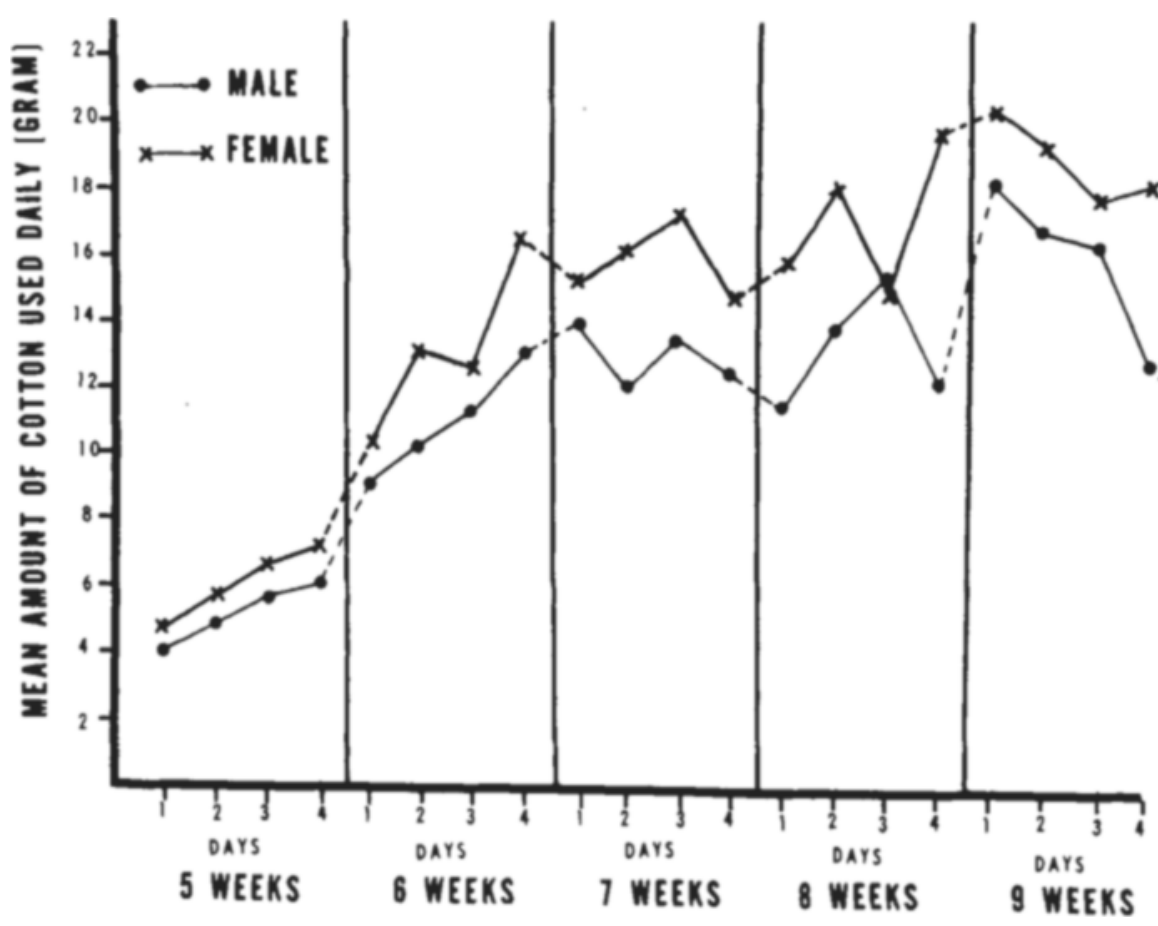

Fig. 2. Cotton consumption by gerbils at various ages.
Procedure

Ss were tested 5 days a week for 5 weeks, starting at 5 weeks of age. The experiment was run between 1:30 and 2:30 p.m. On the first day of the experiment, cotton was placed on top of the cage lid. The weight of cotton and lid was recorded. The difference in weight between the first and the subsequent day was taken as cotton consumption per day. The characteristics of nests were also noted.

\section{Results and Discussion}

Figure 2 shows the amount of cotton used by the gerbils at various ages. The analysis of variance indicated a significant day effect $(F=14.40$, $\mathrm{df}=19 / 342, \mathrm{p}<.01)$. Both males and females used more cotton as they grew older $(F=4.38,7.31$ for males and females, respectively; $\mathrm{df}=19 / 180$ and $\mathrm{p}<.01$ in both cases). This is similar to findings in mice (Lee, 1969), but it differs from reports on rats, which show a higher nesting activity before puberty than at subsequent time (Kinder, 1927). There were neither significant sex differences nor a significant Sex by Day interaction. Similar to mice, deermice, and rats, gerbils do not show differences between males and nonpregnant females in nest activity (Lee, 1969; King, 1963; Layne, 1969; Kinder, 1927). Qualitatively, gerbils used cotton to build nests with tops, bottoms, and edges. The nests are similar to, but less well constructed, than those of $\mathrm{BALB} / \mathrm{cJ}$ mice (Lee, 1969).

\section{REFERENCES}

GLICKMAN, S. E., FRIED, L., \& MORRISON, B. A. Shredding of nesting material in the mongolian gerbil. Perceptual \& Motor Skills, 1967, 24, 473-474.

KINDER, E. F. A study of the nest-building activity of the albino rat. The Journal of Experimental Zoology, 1927, 47, 117-161.

KING, J. A. Matemal behavior in Peromyscus. In H. L. Rheingold (Ed.). Maternal behavior in mammals. New York: Wiley, 1963. Pp. 58-93.

LAYNE, J. N. Nest-building behavior in three species of deer mice, Peromyscus. Behaviour, 1969, 35, 288-303.

LEE, C. T. The nest-building behavior of inbred mice: Developmental and genetic studies. Unpublished doctoral dissertation, Bowling Green State University, Ohio, 1969.

LINDZEY G THIESSEN, D. D. \& TUCKER, A. Development and hormonal control of territorial marking in the male mongolian gerbil, (Meriones unguiculatus). Developmental Psychology, 1968, 1, 97-99.

SCHWENTKER, V. The gerbil: An annotated bibliography. Available from Tumblebrook Farm Inc, Brant Lake, New York, 1968

THIESSEN, D. D. The roots of territorial marking in the mongolian gerbil: A problem of species-common topography. Behavior Research Methods \& Instrumentation, $1968 \mathrm{a}, 1,70-76$.

THIESSEN, D. D. Hormone induction of terrjtorial marking in the female mongolian gerbil (Meriones unguiculatus). The Proceedings of the 76th Annual Convention of American Psychological Association, 1968b, 303-304.

THIESSEN, D. D., FRIEND, H. C, \& LINDZEY, G. Androgen control of territorial marking in the mongolian gerbil. Science, $1968,160,432-434$. 